\title{
SISTEM TANAM HIDROPONIK SAYUR BAYAM MERAH (Amaranthus gangeticus) DENGAN MENGGUNAKAN LIMBAH CAIR TAHU SEBAGAI NUTRISI PERTUMBUHAN
}

\author{
Anita Restu Puji Raharjeng ${ }^{1}$, Awalul Fatiqin ${ }^{2}$, Riri Novita Sunarti ${ }^{3}$ \\ 1,2,3 Universitas Islam Negeri Raden Fatah Palembang, Jl. Prof. K.H. Zainal Abidin Fikri No. 1 A \\ KM 3,5, Palembang 30126, Indonesia \\ *Corresponding author, e-mail: anitaraharjeng_uin@ @adenfatah.ac.id
}

\section{ABSTRACT}

The aims of this research is to know the effect of liquid wastes on vegetative growth of red spinach plants. This research used Factorial Random Design (RAL). Objeks in this research are nutrient solution (L) and planting medium (M). The data was analyzed using two way ANOVA. The treatment in this research is nutrient solution (L) and planting medium (M). There are 2 types of nutrients used, the aquadest and the tofu liquid waste. There are 2 types of medium used, the cocopeat media and sand media. From result of research it is known that, at treatment L1M1 which is treatment with tofu liquid waste on cocopeat planting medium technique obtained high yield of planting with average 7,70 $\mathrm{cm}$. Likewise on the observation of the number of leaves on L1M1 treatment also obtained an average yield of 4.00 pieces. Similarly, at the roots of red spinach plants obtained the highest average, namely the treatment of L1M1 with an average root length of $23.75 \mathrm{~cm}$. Conclusion the use of tofu liquid waste as an additional nutrient for the growth of red spinach vegetable plants has an effect on the vegetative growth of red spinach plants.

Keywords: Hydroponic, Tofu Liquid Waste, Growth

\section{PENDAHULUAN}

Limbah merupakan salah satu penyebab pencemaran lingkungan yang membawa dampak memburuknya kesehatan bagi mayarakat. Dampak buruk tersebut disebabkan oleh limbah cair dari berbagai industri seperti industri pabrik tahu yang dalam proses produksinya menghasilkan limbah cair yang masih banyak mengandung unsur-unsur organik. Unsur organik dalam limbah cair itu mudah membusuk dan mengeluarkan bau yang kurang sedap sehingga selain mencemari air juga dapat mencemari udara sekitar pabrik produksi (Makiyah, 2013).

Industri tahu dalam proses pengolahannya, menghasilkan limbah baik limbah padat maupun cair. Limbah padat tahu berbahaya jika langsung dibuang tanpa pengolahan lebih terlebih dahulu, karena limbah ini dapat merubah kualitas air dan menurunkan kemampuan air di sekitar industri tahu. Sedangkan limbah cair tahu mengandung zat organik yang tinggi misalnya protein, lemak, karbohidrat, mineral, kalsium, fosfor serta zat besi dan nitrogen (Hadiyanto, 2018). Kandungan dalam limbah cair tahu tersebut dapat bermanfaat untuk pertumbuhan tanaman bayam.

Dari beberapa uraian tersebut, bahwasannya dalam limbah yang dipandang tidak dapat digunakan lagi tenyata dapat dimanfaatkan sebagai bahan nutrisi untuk pertumbuhan suatu tumbuhan. Limbah cair tahu tersebut dapat dijadikan sebagai pupuk cair atau larutan nutrisi untuk pertumbuhan tumbuhan. Karena dalam 
pertumbuhan tumbuhan sangat diperlukan nutrisi-nutrisi baik dalam jumlah mikro maupun makro, sehingga tumbuhan dapat tumbuh dengan baik. Mengenai hal tersebut telah diterangkan di dalam Al-Quran yang diwahyukan kepada Nabi Muhammad SAW, dalam surat Ar-Ra'd ayat 4 Allah SWT berfirman yang artinya: "Dan di bumi ini terdapat bagian-bagian yang berdampingan, dan kebun-kebun anggur, tanaman-tanaman dan pohon korma yang bercabang dan yang tidak bercabang, disirami dengan air yang sama. Kami melebihkan sebahagian tanam-tanaman itu atas sebahagian yang lain tentang rasanya. Sesungguhnya pada yang demikian itu terdapat tanda-tanda (kebesaran Allah) bagi kaum yang berfikir."

Sangatlah jelas bahwa, Allah yang dalam firmanNya tersebut menjelaskan kepada hambanya untuk mempelajari apa yang telah diciptakan-Nya di bumi ini. Sekecil apa pun ciptaan-Nya tidaklah mungkin tidak mempunyai arti atau maksud yang menunjukkan kebesaran Allah SWT. Kita sebagai manusia diciptakan sebagai khalifah di bumi ini, kemudian telah dibekali akal oleh Allah mempunyai kewajiban untuk memikirkan dan mengkaji serta meneliti apa yang telah Allah berikan kepada kita.

Berdasarkan hal tersebut, maka perlu dilakukan upaya untuk memikirkan dan menemukan solusi yang tepat terhadap pemanfaatan limbah cair tahu, yang kebanyakan tidak digunakan lagi. Setelah diketahui beberapa kandungan nutrisi di dalam limbah cair tahu tersebut, maka dalam penelitian ini dicoba untuk mengaplikasikan limbah tersebut sebagai tambahan nutrisi bagi pertumbuhan tanaman bayam.

Tanaman bayam digunakan dalam penelitian ini karena penyebaran tanaman bayam di Indonesia telah meluas ke seluruh wilayah dan merupakan tanaman yang biasa digunakan sebagai konsumsi harian masyarakat Indonesia. Data dari Biro Pusat Statistik tahun 1992 menyatakan bahwa dari 34.677 ha luas pertanian bayam, 12.084 ha berada di pulau Jawa dengan total volume produksi dalam satu tahun sebanyak 44.464 ton atau 55\% dari volume produksi nasional dalam tahun tersebut (Bandini dan Aziz, 2001).

\section{METODE}

Penelitian ini adalah jenis penelitian kuantitatif. Penelitian dilaksanakan di Green Corner Hydroponic Palembang selama 1 bulan, mulai tanggal 1 - 31 Agustus 2017. Alat-alat yang digunakan dalam penelitian ini adalah wadah pembibitan atau penyemaian, polybag, mistar, kain penyaring, ember plastik, gunting, pisau/cutter, beker gelas, dan wadah penyimpan nutrisi (bos air 10 liter). Adapun bahan-bahan yang digunakan adalah limbah cair tahu, cocopeat, air, kain planel, kertas label, dan benih bayam merah (Amaranthus gangeticus).

\section{Metode Penelitian}

Penelitian ini menggunakan Rancangan Acak Lengkap (RAL) faktorial. Faktor dalam penelitian ini yaitu larutan nutrisi (L) dan media tanam (M).

a. Faktor I: larutan nutrisi terdiri atas 2 macam yaitu $\mathrm{L}_{0}=$ Air biasa sebagai kontrol dan $\mathrm{L}_{1}=$ limbah cair tahu.

b. Faktor II: media tanam terdiri dari 2 macam yaitu $\mathrm{M}_{1}=$ cocopeat, $\mathrm{M}_{2}=$ media pasir.

$(\mathbf{t}-\mathbf{1})(\mathbf{r}-\mathbf{1})=15$

Dimana $\quad t=$ jumlah perlakuan

$r=$ jumlah ulangan 


\section{Cara Kerja}

Cara kerja penelitian ini sesuai dengan Kusumastuti (2005) dengan modifikasi.

Penyiapan Limbah Cair Ampas Tahu

Menyiapkan limbah cair tahu. Banyaknya larutan yang disiapkan disesuaikan dengan jumlah pot yang akan digunakan dalam penelitian, yaitu sekitar \pm 50.000 ml selama pengamatan, yaitu 4 minggu.

Penyaringan Limbah Cair Tahu sebelum Digunakan

Sebelum menggunakan limbah cair tahu dalam percobaan, terlebih dahulu dilakukan penyaringan dengan menggunakan kain saring. Hal ini bertujuan agar tidak tercampur oleh kerikil-kerikil kecil, pasir, dan sebagainya. Hasil penyaringan kemudian dapat digunakan dalam percobaan yang akan dilakukan.

Penyemaian Bibit Tanaman

Sebelum memulai penanaman dengan sistem hidroponik ini, yaitu dilakukan penyemaian terlebih dahulu. Bibit tanaman yang digunakan adalah benih bayam merah (Amaranthus gangeticus). Penyemaian menggunakan rockwool (sejenis spons) sebagai media persemaiannya.

\section{Pembuatan Tempat Media Tanam}

Terlebih dahulu disiapkan polybag berukuran 12 x $17 \mathrm{~cm}$, kemudian masukkan pada polybag bagian atas tersebut, yaitu medianya menggunakan pasir, dan cocopeat sesuai dengan perlakuan.

\section{Penanaman dan Pemeliharaan}

Kecambah bayam merah (Amaranthus gangeticus) yang telah berdaun 4 dipindahkan pada masing-masing pot/botol yang telah dibuat, yaitu dengan meletakkan bibit yang sudah disemai menggunakan rockwool di tengah (rockwollnya disertakan dalam penanaman). Lalu media tanam sesuai dengan perlakuan (media pasir, sekam bakar, cocopeat), agar bibit tidak bergeser. Bagian bawah botol tersebut diisi $300 \mathrm{ml}$ air ataupun limbah cair sesuai perlakuan. Pergantian air dan limbah cair tahu tersebut dilakukan tiga hari sekali.

\section{Variabel Pengamatan}

Data yang diamati adalah jumlah daun, tinggi tanaman dan panjang akar. Pengukuran dilaksanakan setelah tanaman berumur 7 hari setelah tanam.

Tahap Pengamatan

a. Tinggi tanaman diukur setiap minggu dengan cara mengukurnya dari permukaan atas media sampai dengan ujung tunas daun.

b. Dihitung jumlah daun yang tumbuh sempurna, dilakukan seminggu sekali mulai dari minggu pertama setelah penanaman sampai panen.

c. Kegiatan tersebut dilakukan selama enam minggu, yaitu pada minggu pertama, kedua, ketiga, keempat, kelima, dan keenam setelah pemindahan benih.

\section{HASIL DAN PEMBAHASAN \\ Tinggi Tanaman}

Data tinggi tanaman bayam merah (Amaranthus gangeticus) berdasarkan perlakuan dan ulangan dari pengamatan setiap minggu dapat dilihat pada tabel 1 . Dari tabel 1 dapat diketahui bahwa, hasil rata-rata tinggi tanaman bayam merah yang telah dihitung dari pengamatan 1 - 4 MST (minggu setelah tanam), pada larutan air biasa dengan media tanam cocopeat (hidroponik) (L0M1) berkisar 6,48 cm, pada larutan air biasa dengan media tanam pasir (L0M2) berkisar 4,84 cm, pada larutan limbah cair tahu dengan media tanam cocopeat (hidroponik) (L1M1) berkisar 6,98 
$\mathrm{cm}$, dan pada larutan limbah cair tahu dengan media tanam pasir (L1M2) berkisar $2,53 \mathrm{~cm}$.

Tabel 1. Data Rata-rata Hasil Pengamatan Tinggi Tanaman Bayam Merah

\begin{tabular}{cccccccc}
\hline \multirow{2}{*}{ Perlakuan } & \multicolumn{7}{c}{ Minggu Ke- } \\
\cline { 2 - 6 } & $\mathbf{1}$ & $\mathbf{2}$ & $\mathbf{3}$ & $\mathbf{4}$ & $\mathbf{5}$ & $\mathbf{6}$ & Rata-rata \\
\hline L0M1 & 5.50 & 6.18 & 6.50 & 6.68 & 6.90 & 7.13 & 6.48 \\
L0M2 & 4.25 & 4.58 & 4.88 & 4.95 & 5.10 & 5.30 & 4.84 \\
L1M1 & 5.83 & 6.50 & 7.13 & 7.22 & 7.50 & 7.70 & 6.98 \\
L1M2 & 2.00 & 1.70 & 2.50 & 2.88 & 2.99 & 3.15 & 2.53 \\
\hline
\end{tabular}

Data yang diperoleh kemudian dilakukan analisis sidik ragam dengan pola RAL, dengan empat perlakuan dan enam ulangan. Dapat diketahui hasil analisis tersebut pada tabel 2. Hasil uji lanjut dengan uji Duncan taraf 5\%, karena nilai KK (Koefisien Keragaman) yang dihasilkan sebesar 34,70\%, dapat dilihat pada tabel 3.

Tabel 2. Analisis Data Pengaruh Limbah Cair Tahu terhadap Tinggi Tanaman Bayam Merah

\begin{tabular}{cccccc}
\hline SK & DB & JK & KT & $\mathbf{F}_{\text {hitung }}$ & $\begin{array}{c}\mathbf{F}_{\text {Tabel }} \text { * } \\
\mathbf{5 \%}\end{array}$ \\
\hline Media Tanam (A) & 1 & 61,05 & 61,05 & 14,92 & 4,35 \\
Larutan (B) & 1 & 3,74 & 3,74 & 0,91 & 4,35 \\
Galat (G) & 20 & 81,91 & 4,09 & & \\
Total & 23 & 157,81 & & & \\
\hline
\end{tabular}

Keterangan :

* = berbeda nyata

Tabel 3. Hasil Uji Duncan Tinggi Tanaman Bayam Merah

\begin{tabular}{|c|c|c|c|c|c|}
\hline \multirow{2}{*}{ Perlakuan } & \multirow{2}{*}{$\begin{array}{c}\text { Rata-rata } \\
\text { Hasil }\end{array}$} & \multicolumn{3}{|c|}{ Beda Jarak Nyata } & \multirow{2}{*}{$\begin{array}{l}\text { BJND } \\
0,05\end{array}$} \\
\hline & & 2 & 3 & 4 & \\
\hline L1M2 & 3,15 & - & & & A \\
\hline L0M2 & 5,30 & 2,15 & - & & A \\
\hline L0M1 & 7,13 & 1,83 & 3,98 & - & B \\
\hline L1M1 & 7,70 & 0,57 & 2,40 & 4,55 & B \\
\hline \multicolumn{2}{|c|}{$\mathrm{R}_{00.5}(\mathrm{P} .12)$} & 2,95 & 3,10 & 3,18 & \\
\hline \multicolumn{2}{|c|}{ BJND 00.5} & 0,88 & 0,93 & 0,95 & \\
\hline
\end{tabular}

Hasil penelitian menunjukkan bahwa perlakuan dengan tambahan nutrisi limbah cair tahu dan media tanam memiliki pengaruh terhadap pertumbuhan tanaman bayam merah. Berdasarkan hasil analisis sidik ragam (tabel 2.) menunjukkan bahwa dari hasil perhitungan ANOVA dua jalur diperoleh untuk media tanam $\mathrm{F}_{\text {hitung }}$ sebesar 14,92 dan nilai $\mathrm{F}_{\text {tabel }}$ pada taraf $5 \%=4,35$ ( $\mathrm{F}_{\text {hitung }}$ lebih besar daripada $\left.\mathrm{F}_{\text {tabel }}\right)$. Sedangkan pada penambahan limbah cair tahu yaitu $\mathrm{F}_{\text {hitung }}$ sebesar 0,91 , sehingga $F_{\text {hitung }}$ tersebut lebih besar nilainya daripada $F_{\text {tabel }}$ pada taraf $5 \%=4,35$ ( $\mathrm{F}$ hitung $>\mathrm{F}$ tabel). Artinya penambahan nutrisi limbah cair tahu memiliki pengaruh yang nyata terhadap tinggi tanaman bayam merah.

Adapun hasil rata-rata tinggi tanaman bayam merah yang telah dihitung dari pengamatan 1 - 4 MST (minggu setelah tanam), dapat diketahui bahwa pada larutan air biasa dengan media tanam cocopeat (hidroponik) (L0M1) berkisar 6,48 cm, pada 
larutan air biasa dengan media tanam pasir (L0M2) berkisar 4,84 cm, pada larutan limbah cair tahu dengan media tanam cocopeat (hidroponik) (L1M1) berkisar 6,98 $\mathrm{cm}$, dan pada larutan limbah cair tahu dengan media tanam pasir (L1M2) berkisar $2,53 \mathrm{~cm}$.

Pada perlakuan L1M1 yakni penambahan larutan limbah cair tahu dengan media tanam cocopeat (hidroponik) rata-rata tinggi tanaman bayam merah diperoleh $6,98 \mathrm{~cm}$. Pada perlakuan ini, penanaman bayam merah pada media tanam cocopeat (hidroponik) merupakan rata-rata tinggi tanaman paling tinggi. Pertumbuhan tanaman bayam merah pada perlakuan ini cukup baik.

Tinggi tanaman dipengaruhi dengan adanya unsur makro dan unsur mikro media. Unsur hara (makro dan mikro) yang tersedia bagi tanaman akan dengan mudah dimanfaatkan tanaman untuk meningkatkan pertumbuhan tanaman (Hakim, 2006). Dalam penelitian ini, limbah cair tahun memiliki banyak kandungan $\mathrm{N}$ yang merupakan unsur makro yang mempengaruhi pertumbuhan tinggi tanaman. Ditambah lagi pH limbah cair tahu yang digunakan memiliki pH 6 yang merupakan pH yang sesuai untuk absorbsi zat N ke dalam tanaman (Saputri, 2015).

\section{Jumlah Daun}

Data yang didapat dari hasil penelitian, jumlah daun tanaman bayam merah (Amaranthus gangeticus) berdasarkan perlakuan dan ulangan dari pengamatan setiap minggu dapat dilihat pada tabel 4.

Tabel 4. Data Rata-rata Hasil Pengamatan Jumlah Daun Tanaman Bayam Merah

\begin{tabular}{|c|c|c|c|c|c|c|c|}
\hline \multirow{2}{*}{ Perlakuan } & \multicolumn{6}{|c|}{ Minggu Ke- } & \multirow{2}{*}{ Rata-rata } \\
\hline & 1 & 2 & 3 & 4 & 5 & 6 & \\
\hline L0M1 & 5,25 & 5,00 & 3,75 & 3,50 & 3,25 & 3,00 & 3,95 \\
\hline L0M2 & 4,50 & 3,25 & 2,75 & 2,00 & 1,75 & 1,50 & 2,63 \\
\hline L1M1 & 5,50 & 5,25 & 4,75 & 4,50 & 4,25 & 4,00 & 4,70 \\
\hline L1M2 & 4,50 & 4,25 & 4,00 & 3,75 & 3,50 & 3,50 & 3,91 \\
\hline
\end{tabular}

Dari data pengamatan rata-rata jumlah daun dapat diketahui bahwa rata-rata jumlah daun tanaman bayam merah yang telah dihitung dari pengamatan $1-4$ MST (Minggu Setelah Tanam), pada larutan air biasa dengan media tanam cocopeat (hidroponik) (L0M1) adalah 3,95 helai, pada larutan air biasa dengan media tanam pasir (L0M2) adalah 2,63 helai, pada larutan limbah cair tahu dengan media tanam cocopeat (hidroponik) (L1M1) adalah 4,70 helai, dan pada larutan limbah cair tahu dengan media tanam pasir (L1M2) adalah 3,91 helai.

Tabel 5. Analisis Sidik Ragam Pengaruh Limbah Cair Tahu terhadap Jumlah Daun Tanaman Bayam Merah

\begin{tabular}{cccccc}
\hline SK & DB & JK & KT & F $_{\text {hitung }}$ & $\begin{array}{c}\mathbf{F}_{\text {Tabel }} \\
\text { * }^{\mathbf{5} \%}\end{array}$ \\
\hline Media Tanam (A) & 1 & 6 & 6 & 4 & 4,35 \\
Larutan (B) & 1 & 13,6 & 13,6 & 9 & 4,35 \\
Galat (G) & 20 & 30 & 1,5 & & \\
Total & 23 & 51 & & & \\
Keterangan: & & & & \\
$*$ = berbeda nyata & & & &
\end{tabular}


Kemudian dari data tersebut dilakukan analisis sidik ragam dengan pola RAL dengan empat perlakuan dan enam kali ulangan. Adapun hasil analisis tersebut dapat dilihat pada tabel 5 .

Berdasarkan hasil KK (Koefisien Keragaman) yang telah didapatkan yaitu sebesar 40,82\%, maka uji lanjut yang dilakukan adalah dengan menggunakan Uji Duncan taraf 5\% seperti pada tabel 6.

Tabel 6. Hasil Uji Duncan Jumlah Daun Tanaman Bayam Merah

\begin{tabular}{cccccc}
\hline \multirow{2}{*}{ Perlakuan } & $\begin{array}{c}\text { Rata-rata } \\
\text { Hasil }\end{array}$ & $\mathbf{2}$ & $\mathbf{3}$ & $\mathbf{4}$ & $\begin{array}{c}\text { BJND } \\
\mathbf{0 , 0 5}\end{array}$ \\
\cline { 3 - 5 } L0M2 & 1,50 & - & & & $\mathrm{A}$ \\
L0M1 & 3,00 & 1,50 & - & & $\mathrm{B}$ \\
L1M2 & 3,50 & 0,50 & 2,00 & - & $\mathrm{C}$ \\
L1M1 & 4,00 & 0,50 & 1,00 & 2,50 & $\mathrm{D}$ \\
\multicolumn{2}{c}{ R $_{00.5}(\mathrm{P} .12)$} & & 2,95 & 3,10 & 3,18 \\
\multicolumn{2}{c}{ BJND 00.5} & 0,59 & 0,62 & 0,63 & \\
\hline
\end{tabular}

Pada perlakuan L0M1 rerata jumlah daun bayam merah tiap minggunya mengalami penurunan (tabel 4). Hal ini disebabkan karena adanya faktor lain yang menyebabkan daun menjadi kering dan akhirnya rontok. Faktor tersebut diantaranya adanya penyakit dan hama yang menyerang tanaman. Begitu juga pada perlakuan L0M2, L1M1, dan perlakuan L1M2 setelah dilakukan pengamatan selama empat minggu rerata jumlah daun selalu mengalami penurunan. Menurut Rukmana (1995), hama yang merusak pertanaman sayur yaitu ulat tanah, kutu daun, dan tungau, sedangkan penyakit yang sering ditemukan adalah bercak septoria, bercak cercospora, nematoda akar, dan hawar daun bakteri.

Menurut Wasonowati (2011), pengaruh tinggi tanaman berkaitan dengan bertambahnya jumlah dan ukuran sel serta pembentukan jaringan yang sebanding dengan pertumbuhan batang daun dan sistem perakarannya. Pertumbuhan tinggi tanaman menunjukkan aktivitas pembentukan xylem dan pembesaran sel-sel yang tumbuh. Aktivitas ini menyebabkan kambium terdorong keluar dan terbentuknya selsel baru di luar lapisan-lapisan tersebut sehingga terjadi peningkatan tinggi tanaman.

Pada pengamatan jumlah daun tanaman bayam merah ini dilakukan penghitungan satu minggu sekali (1-4 MST). Jumlah daun yang tumbuh menunjukkan rata-rata hasil yang berbeda-beda. Adapun hasil akhir jumlah daun tanaman bayam merah (tabel 6) memiliki rata-rata yaitu pada larutan air biasa dengan media tanam cocopeat (hidroponik) (L0M1) adalah 3,95 helai, pada larutan air biasa dengan media tanam pasir (LOM2) adalah 2,63 helai, pada larutan limbah cair tahu dengan media tanam cocopeat (hidroponik) (L1M1) adalah 4,70 helai, dan pada larutan limbah cair tahu dengan media tanam pasir (L1M2) adalah 3,91 helai.

Jumlah helaian daun tanaman dipengaruhi oleh keberadaan makro dan mikro nutrient dalam media. Menurut Maillard, dkk., (2015) disebutkan bahwa ketidakadaan unsur $\mathrm{N}$ akan mengakibatkan penuaan pada daun. Limbah cair tahu kaya akan unsur $\mathrm{N}$, sehingga unsur ini mendorong perbanyakan dan pertumbuhan daun tanaman. Selain itu, unsur Ca dan Mn yang terkandung dalam limbah cair tahu dapat memacu pertumbuhan floem tanaman. Unsur K, P dan Mg diketahui memiliki peran penting dalam pemasakan buah dan pertumbuhan vegetatif. Ditambah pula dengan kondisi pH yang sesuai yaitu 6 mengakibatkan unsur - unsur tersebut mudah untuk diserap dan diedarkan di seluruh bagian tanaman. 


\section{Panjang Akar}

Pada pengamatan panjang akar ini dilakukan pengukuran satu kali, yaitu panjang akar diukur pada minggu keempat atau pada akhir pengamatan. Berdasarkan perlakuan dan ulangan dari pengamatan yang dilakukan, diperoleh data hasil penelitian panjang akar tanaman bayam merah (Amaranthus gangeticus) pada tabel 7.

Tabel 7. Rata-rata Hasil Pengamatan Tanaman Bayam Merah

\begin{tabular}{|c|c|c|c|c|c|c|c|}
\hline \multirow{2}{*}{ Perlakuan } & \multicolumn{6}{|c|}{ Ulangan } & \multirow{2}{*}{ Rata-rata } \\
\hline & 1 & 2 & 3 & 4 & 5 & 6 & \\
\hline L0M1 & 19 & 14,6 & 20 & 17 & 18 & 15 & 17,26 \\
\hline L0M2 & 23 & 25 & 11,5 & 15 & 10 & 13 & 16,25 \\
\hline L1M1 & 30 & 21 & 15,5 & 41 & 15 & 20 & 23,75 \\
\hline L1M2 & 8,4 & 15 & 11 & 9 & 7 & 12 & 10,91 \\
\hline
\end{tabular}

Dari data hasil pengamatan rata-rata panjang akar tanaman bayam merah, dapat diketahui bahwa pada larutan air biasa dengan media tanam cocopeat (hidroponik) (L0M1) berkisar 17,26 cm, pada larutan air biasa dengan media tanam pasir (L0M2) berkisar $16,25 \mathrm{~cm}$, pada larutan limbah cair tahu dengan media tanam cocopeat (hidroponik) (L1M1) berkisar 23,75 cm, dan pada larutan limbah cair tahu dengan media tanam pasir (L1M2) berkisar 10,91 cm. Kemudian dari data tersebut dilakukan analisis sidik ragam dengan pola RAL dengan empat perlakuan dan enam kali ulangan. Adapun hasil analisis tersebut dapat dilihat pada tabel 8.

Tabel 8. Analisis Sidik Ragam Pengaruh Limbah Cair Tahu terhadap Panjang Akar Tanaman Bayam Merah

\begin{tabular}{cccccc}
\hline SK & DB & JK & KT & $\mathbf{F}_{\text {hitung }}$ & $\mathbf{F}_{\text {Tabel }}$ * $^{\mathbf{5} \%}$ \\
\hline Media Tanam (A) & 1 & 274,72 & 274,72 & 7,19 & 4,35 \\
Larutan (B) & 1 & 168,72 & 168,72 & 4,41 & 4,35 \\
Galat (G) & 20 & 763,69 & 38,18 & & \\
Total & 23 & 1470,18 & & & \\
\hline
\end{tabular}

Keterangan:

$*$ = berbeda nyata

Berdasarkan hasil analisis data (tabel 8), didapatkan nilai KK (Koefisien Keragaman) adalah 36,50\%. Adapun selanjutnya untuk mengetahui perbedaan pengaruh masing-masing perlakuan dilakukan uji lanjut. Berdasarkan hasil KK (Koefisien Keragaman) yang didapatkan, maka uji lanjut yang dilakukan untuk pengamatan panjang akar ini adalah dengan menggunakan Uji Duncan taraf $5 \%$, seperti pada tabel 9.

Pada pengamatan panjang akar, dilakukan satu kali selama penelitian yaitu pada akhir panelitian (minggu ke-4 pengamatan). Adapun data rata-rata yang diperoleh pada larutan air biasa dengan media tanam cocopeat (hidroponik) (L0M1) berkisar 17,26 cm, pada larutan air biasa dengan media tanam pasir (L0M2) berkisar $16,25 \mathrm{~cm}$, pada larutan limbah cair tahu dengan media tanam cocopeat (hidroponik) (L1M1) berkisar 23,75 cm, dan pada larutan limbah cair tahu dengan media tanam pasir (L1M2) berkisar 10,91 cm. Data dari hasil pengukuran panjang akar tersebut menunjukkan rata-rata yang berbeda-beda. 
Tabel 9. Hasil Uji Duncan Panjang Akar Tanaman Bayam Merah

\begin{tabular}{cccccc}
\hline \multirow{2}{*}{ Perlakuan } & $\begin{array}{c}\text { Rata-rata } \\
\text { Hasil }\end{array}$ & \multicolumn{3}{c}{ Beda Jarak Nyata } & BJND \\
\cline { 3 - 6 } & & $\mathbf{2}$ & $\mathbf{3}$ & $\mathbf{4}$ \\
\hline L1M2 & 10,46 & - & & & $\mathrm{A}$ \\
L0M2 & 16,25 & 5,79 & - & $\mathrm{A}$ \\
L0M1 & 17,26, & 1,01 & 11,47 & - & $\mathrm{A}$ \\
L1M1 & 23,75 & 6,49 & 7,50 & 17,96 & $\mathrm{~B}$ \\
\multicolumn{2}{c}{ R $_{00.5}(\mathrm{P} .18)$} & 2,95 & 3,10 & 3,18 & \\
\multicolumn{2}{c}{ BJND 00.5} & 3,00 & 3,16 & 3,24 & \\
\hline
\end{tabular}

Dari hasil yang diperoleh, diketahui bahwa pada perlakuan kontrol yakni dengan larutan nutrisi air biasa akar tanaman memanjang sampai ke tempat larutan nutrisi. Sedangkan pada perlakuan dengan penambahan larutan nutrisi limbah cair tahu, akar hanya berada pada media tanam, dan jumlah akar yang tumbuh pada tanaman cukup banyak. Berbeda dengan perlakuan kontrol, jumlah akar lebih sedikit dan berukuran panjang-panjang.

Adapun penyebab terlalu panjangnya akar pada perlakuan kontrol tersebut yaitu sangat minimnya kandungan nutrisi yang ada pada larutan air biasa tersebut. Sedangkan media tanam dengan teknik hidroponik hanyalah sebagai penopang tanaman, dan pada media tanam tersebut jumlah nutrisi yang dikandungnya juga sedikit sehingga perlu penambahan nutrisi dari luar yang dibutuhkan oleh tanaman untuk tumbuh. Jika nutrisi yang dibutuhkan tumbuhan kurang tersedia bagi tumbuhan, maka akan menyebabkan akar berusaha untuk selalu mencari nutrisi yang dibutuhkan oleh tumbuhan tersebut. Menurut Rosliana (2005), menyatakan bahwa pemberian larutan hara yang teratur sangatlah penting pada hidroponik, karena media hanya berfungsi sebagai penopang tanaman dan sarana meneruskan larutan atau air yang berlebihan. Pada media tanam kandungan nutrisi jumlahnya hanya sedikit, sehingga kebutuhkan nutrisi bagi tumbuhan kurang terpenuhi.

Panjang akar sangat dipengaruhi oleh keberadaan makro dan mikro nutrient dalam media. Maillard, dkk., (2015) menyatakan bahwa unsur K, P dan Mg diketahui memiliki peran penting dalam perpanjangan akar dan merupakan unsur utama dalam perkecambahan. Limbah cair tahu memiliki kandungan $\mathrm{K}$ dan $\mathrm{P}$ yang tinggi, yang mana dengan kondisi pH yang sesuai yaitu 6 mengakibatkan unsur - unsur tersebut mudah untuk diserap dan diedarkan di seluruh bagian tanaman.

\section{SIMPULAN}

Penggunaan limbah cair tahu sebagai tambahan nurisi pertumbuhan tanaman sayur bayam merah, berpengaruh terhadap pertumbuhan vegetatif tanaman bayam merah. Media tanam pasir lebih optimum untuk pertumbuhan bayam merah ialah pada penggunaan larutan air biasa.

\section{UCAPAN TERIMA KASIH}

Terimakasih ditujukan kepada LP2M UIN Raden Fatah Palembang telah memberikan hibah dana penelitian pada tahun anggaran 2017.

\section{REFERENSI}

Bandini, Y. \& Aziz, N. (2001). Bayam. Jakarta. Penebar Swadaya.

Hadiyanto, H. (2018). Ozone Application for Tofu Waste Water Treatment and Its Utilisation for Growth Medium of Microalgae Spirulina sp. International 
Conference on Energy, Environmental and Information System (ICENIS 2017). https://doi.org/10.1051/e3sconf/20183103002.

Hakim, N. (2006). Pengelolaan Kesuburan Tanah Masam dengan Teknologi Pengapuran Terpadu. Padang: Andalas University Press.

Kusumastuti, T.A. (2005). Analisis Manfaat dan Biaya Sosial Limbah Industri Tahu dan Limbah Peternakan di Daerah Pedesaan. Jurnal Manusia dan Lingkungan, 12 (1), 1-12. https://doi.org/10.22146/jml.18629

Makiyah, M. (2013). Analisis Kadar N, P dan K pada Pupuk Cair Limbah Tahu dengan Penambahan tanaman matahari Meksiko (Thitonia diversivolia) (Skripsi). Semarang: Fakultas Matematika dan Ilmu Pengetahuan Alam Universitas Negeri Semarang.

Maillard, A., Diquélou, S. Billard, V. Laîné, P. Garnica, M. Prudent, M. Garcia-Mina, J-M., Yvin, J.C. \& Ourry, A. (2015). Leaf Mineral Nutrient Remobilization During Leaf Senescence and Modulation by Nutrient Deficiency. Front Plant Sci, 6(317), 1-15. doi: 10.3389/fpls.2015.00317.

Rosliana, R \& Sumarni, N. (2005). Budidaya Tanaman Sayuran dengan Sistem Hidroponik. Lembang: Balai Penelitian Tanaman Sayur.

Rukmana. (1995). Bertanam Seledri. Yogyakarta. Kanisius.

Saputri, R.N.R. (2015). Pengolahan Air Limbah Cair Pabrik Tahu. Semarang: Universitas Diponegoro.

Wasonowati, C. (2011). Meningkatkan Pertumbuhan Tanaman Tomat (Lycopersicon esculentum) dengan Sistem Budidaya Hidroponik. Fakultas Pertanian. Universitas Trunojoyo Madura. 